\title{
Analysis Efficiency of Luwak Coffee Business
}

\author{
Niken Dwinora, Eko Sumartono, Bambang Sumantri \\ Department of Agricultural Socio-Economics, Faculty of Agriculture University of Bengkulu \\ Email: eko_sumartono@unib.ac.id
}

\begin{abstract}
The purposes of this study were to 1) Calculate the amount of profit from the civet coffee processing business in Bandung Jaya Village, Kabawetan District, Kepahiang Regency. 2) To calculate the efficiency of the civet coffee business in Bandung Jaya Village, Kabawetan Subdistrict, Kepahiang Regency, with consideration that in Bandung jaya Village, Kabawetan Subdistrict, Kepahiang Regency has the most sought after sales of civet coffee. Sampling was done by using the Purposive Method. Because the researchers intentionally took the data in the Luwak Coffee business stamp well in Bandung Jaya Village, Kabawetan District, Kepahiang District, the data analysis used the R / C ratio and B / C methods. The results showed that the efficiency analysis of R / C Ratio showed that Luwak coffee business was very efficient because revenues were greater than the total production costs. The results of the B / C Ratio analysis showed that these business ws not feasible because income is lower than the total production cost.
\end{abstract}

Keywords: Luwak Coffee; efficiency; civet coffee business;

Citation to this paper should be made as follows :

Dwinora, N. Sumartono, E. Sumantri, B. 2018. Analysis Efficiency Of Luwak Coffee Business. Agritropica: Journal of Agricultural Science. 1 (2): 78-84. DOI: https:// doi.org/10.31186/J.Agritropica.1.2.78-84

\section{INTRODUCTION}

Indonesia is an agricultural country that has fertile land and is a very strategic field in agriculture because it is related to human labor. The agricultural sector is a necessity that's important both from food, feed and the board. The agricultural sector, especially the food sector, is the highest income producer in Indonesia which will increase the economy which will lead to good welfare.

The development of the food processing industry in Indonesia, which is supported by agricultural natural resources, both vegetable and animal that are able to produce various processed products that can be made and developed from local or regional natural resources. At present in several Asian countries many food products are raised from local food types and processed traditionally. With the development of these local products, the number and type of food products are increasing in number (Soleh, 2003).

According to Widianti, E (2010), this small-scale industrial business that has developed in Indonesia is in the food sector. According to Wirakartakusumah (1997), one of the most important sectors whose role is the food industry will increase the Indonesian economy. Because it is able to meet the needs of food in Indonesia, the food industry is also able to increase foreign exchange. And the emergence of labor is needed to assist in managing the industry in the food sector which will encourage the advancement of an industry from year to year. Can also meet supporting needs such as food additives industry, packaging industry, machinery industry and food processing equipment and agribusiness industry.

Processing coffee fruit into coffee powder is an action that will add economic value in it which usually only earns a little income by converting coffee beans into coffee powder, so the economic value is there. And materials that are easily compacted.

The potential of coffee beans owned in Kabawetan district does exist. With the existence of a home industry that manages various kinds of processed coffee beans into several types. Such as red coffee powder, orijinal coffee bean powder, Robusta coffee 
powder, Arabica coffee powder and the most famous and tastes good at an expensive price, namely civet coffee powder. They also sell coffee beans that are unruly black. It is these unripe seeds that are ground into coffee powder.

Processing is carried out by the community, especially the people of Kepahiang regency who process red coffee beans to be used as civet coffee beans by giving red coffee beans as mongoose food. Their mongoose is obtained from farmers who catch Lusang on their land. Farmed mongoose is a nuisance animal. But in farmers who manage civet coffee, mongoose is an animal that is very useful for the fermentation process of red coffee, especially Arabica coffee. Mongoose coffee beans are indeed released from a very disgusting process, but because the taste is very good, it makes people not see the process again, but they prefer to taste the taste that is very delicious from civet coffee.

Taking into account the preferences of consumers for civet coffee, so many of our farmers run this business. Increase the amount of production and it is likely that the benefits will be greater as well.

In any other business, the home industry of an individual generally has the nature of confidentiality over the financial statements or all information relating to the business financial problems that he is currently living, with reasons that are as diverse as so that they cannot be utilized by other business people. Because of this, there are many individual home industry owners who feel they don't need to make financial reports and their analysis. Even though this report is very necessary. Because we can know whether it is worthy or not worthy of this effort. Because of that revenue and income, we can usually see whether the business is efficient or not. With a financial report book, efficient business can be measured.

This condition also causes the sole owner of an individual civet coffee business to not be able to monitor the health condition of the company from time to time and this causes the owner not to have a strong foundation in making strategies in marketing their products. It will even be very dangerous when the individual business owner does not realize that his company is heading for bankruptcy.
So from that it is necessary to analyze a business efficiency that will lead to a clearer advantage in an enterprise if this business does work well with good or no benefits at all (Suryanto et al, 2016).

The purpose of this study is to calculated the amount of profit from the civet coffee processing business in Bandung Jaya Village, Kabawetan District, Kepahiang Regency and to calculate the efficiency of the civet coffee business in Bandung Jaya Village, Kabawetan District, Kepahiang District.

\section{RESEARCH METHODS}

\section{Location and Time of Research}

The location is the focus of this field lecture done purposively, namely the civet coffee processing business located in Kabawetan district, Kepahiang Regency. The researcher chose this location with the consideration that in this district there was a household business belonging to "Bapak Suwandi" which was classified as a home industry that processed the civet coffee business and had been visited by many consumers. This research was conducted in November 2017.

\section{Sample Determination Method}

In this study, the researcher used the purposive method. Because intentionally or directly making a good civet coffee business is used as a respondent in the Luwak Cap Home industry business which produces processed Luwak Coffee located in Bandung Jaya Village, Kabawetan District, Kepahiang Regency.

\section{Data Analysis Method}

\section{Business Efficiency Analysis}

a. Rentrun / Cost ratio ( $\mathrm{R} / \mathrm{C}$ ratio) is a comparison value between the total revenue of Luwak coffee business and the total cost of civet coffee for one year.

\section{a. Cost}

The total cost is the sum of the fixed costs and variable costs of the civet coffee business in Bandung Jaya Village, Kabawetan District, Kepahiang District. Cost has a formula (Soekartawi 2002):

$$
\mathrm{TC}=\mathrm{FC}+\mathrm{VC}
$$

Information: 
$\mathrm{TC}=$ total cost (total cost)

$\mathrm{FC}=$ fixed cost (fixed coost)

$\mathrm{VC}=$ variable cost (variable cost)

\section{b. Income}

Income is the money value of the total product or the product of the multiplication of total production and the price of production. Income analysis formula (Soekartawi, 2002):

$\mathrm{Pd}=\mathrm{TR}-\mathrm{TC}$

$\mathrm{TR}=\mathrm{Y}$. Py

Information:

$\mathrm{Pd}=$ income of civet coffee business

$\mathrm{TR}=$ total revenue (total revenue)

$\mathrm{TC}=$ total cost (total cost)

$\mathrm{TR}=$ total revenue (total revenue)

$\mathrm{Y}=$ production obtained in a civet coffee business

Py $=$ price $Y$

Business efficiency is a measure to see the success of a civet coffee business that can be assessed in terms of the amount of cost to achieve a business that is more developed and can run well in the future. Efficiency measurement can be seen from, if $\mathrm{R} / \mathrm{C}>1$ then we can say efficient and if $R / C<1$ then it is not efficient or it needs to be unfeasible to develop (soekartawi, 2002). Business efficiency formula:

Information:

$$
\mathrm{a}=\mathrm{R} / \mathrm{C}
$$

$\mathrm{a}=\mathrm{R} / \mathrm{C}$ ratio

$\mathrm{R}=$ acceptance

$\mathrm{C}=\cos \mathrm{t}(\cos \mathrm{t})$

The criteria:

1. If $R / C>1$, then it is profitable or feasible business to continue in the next period

2. If the $\mathrm{R} / \mathrm{C}<1$ does not impinge or the business is not feasible to continue

Benefit / Cost Ratio (B / C Ratio)

Is the ratio of the total present value of benefits and costs. A viable alternative criterion is a B / C ratio greater than 1 and an alternative that has the highest B / C Ratio at the first level (Wijaya et al. 2011). B / C Ratio are a measure of the comparison between income (benefit) and the total cost of production (Cost), with the formula:

B / C Ratio $=($ Total Revenue $) /$

Criteria:
1. B / C Ratio> 1: profitable or feasible business carried out

2. B / C Ratio <1: Not profitable or business is not feasible

\section{RESULTS AND DISCUSSION}

\section{Technical and Production Aspects \\ Business Location}

The location of the civet coffee business "Mr. Suwandi" is located in Bandung Jaya Village, Kabawetan District, Kepahiang Regency, Bengkulu City. Location of civet coffee business is close to residential areas. This is what supports many people or consumers easily in buying a copy of the mongoose "Mr. Suwandi" plus the mongoose coffee business is easy in finding sources of raw materials. Both from the coffee raw material it self and mongoose animals to produce civet coffee beans.

The mongoose animal is placed in a cage next to the house "Mr. Suwandi". Therefore from the process of taking civet seeds closer. Even drying is close to the cage because of the cage and drying place beside the house of Mr. Suwandi himself because there is an empty land next to the house "Mr. Suwandi" which is specifically for the process of drying civet coffee.

\section{Production facilities and equipment}

Production facilities and equipment owned by the Luwak coffee business "Mr. Suwandi" includes:

\section{Cage}

The cage used is $4 \times 5$ meters with an economic life of around 10 years. The cage in the form of a house made of concrete and roof tile. Inside is an iron bar. There are 16 iron barriers in the cage. Used to separate the mongoose owned by "Mr. Suwandi". In one skate iron in the cage there are 2-3 mongooses. The floor is cement and there are a few tree branches for mongoose playgrounds. Sometimes is placed fruits to eat mongoose.

\section{Equipment}

The equipment and equipment used in the Luwak coffee business are roasting machines (frying machines), fresh machines, huller machines, coffee pounding machines, 
large scales, electric scales, small scales, medium scales.

\section{Feed}

The feed given to Luwak is usually in the form of papaya, milk, and chicken head. For food, it is given in the morning and evening. Milk is given twice a month as much as 20 liters. While the chicken head is given once a month as much as $3 \mathrm{~kg}$.

\section{Marketing Aspect}

Marketing in a business is an absolute thing that must be done or a main activity other than production which is useful to maintain the continuity of its business and get a profit (profit). The marketing channels carried out by this business are quite modern because many are ordering orders for civet coffee online and as for those who come directly to the civet coffee business in Bandung Jaya village.

\section{Aspects of Business Costs of Civet Coffee}

Luwak coffee production process is carried out for one week. As long as the production costs quite a lot in this civet coffee, starting from mongoose feed, equipment, labor, and other production facilities. The costs incurred by Mr. Suwandi consist of fixed costs and variable costs.

\section{Marketing Aspect}

Marketing in a business is an absolute thing that must be done or a main activity other than production which is useful to maintain the continuity of its business and get a profit (profit). The marketing channels carried out by this business are quite modern because many are ordering orders for civet coffee online and as for those who come directly to the civet coffee business in Bandung Jaya village.

\section{Fixed cost}

Fixed costs are costs incurred by Luwandi Mr. Suwandi's coffee business in Bandung Jaya Village, Kabawetan district, Kepahiang Regency for a business year whose size is not directly related to the amount of production issued by Luwak coffee business during the civet coffee business. The fixed costs incurred by the civet coffee business in
Bandung Jaya Village, Kabawetan District, Kepahiang Regency are as follows:

Table 1. Fixed costs of luwak coffee business in Bandung Jaya Village, Kabawetan District, Kepahiang Regency

\begin{tabular}{clcr}
\hline No & Description & IDR & $\begin{array}{c}\text { Percent } \\
(\%)\end{array}$ \\
\hline 1 & $\begin{array}{l}\text { Equipment } \\
\text { Depreciation } \\
\text { Costs }\end{array}$ & $15,923,333.33$ & 44.91 \\
2 & Labor Costs & $19,530,000.00$ & 55.09 \\
\hline & Total & $35,453,333.33$ & 100
\end{tabular}

Source: Primary Data Processed (2018)

Based on table 1 above, the total fixed costs incurred by Mr. Suwandi in his civet coffee business for one year are IDR. 35,453,333.33 / year. These costs consist of depreciation costs and labor costs. The total depreciation cost of the tool is IDR. $15,923,333.33$ / year or with $44.91 \%$ percent of fixed costs, while labor costs amounting to IDR. $19,530,000.00$ / year or with $55.09 \%$ percent.

\section{Variable Costs}

Variable costs of civet coffee business are costs incurred for purposes for one business year and the amount is influenced by the amount of production produced. The average cost spent every year is IDR. $22,911,000$ / year. These costs can be seen in the table below:

From table 2 above, it can be seen that the total variable costs incurred during the one-year period in Mr. Suwandi's Luwak coffee business in Bandung Jaya Village, Kabawetan District, Kepahiang Regency are IDR. 22,911,000 / year. Of the total costs that exist in the variable cost component, the cost of feed is the greatest by spending a fee of IDR. $5,160,000$ / year. The biggest feed cost is because the feed given to the civet is many variants so that mongoose is not bored in eating coffee fruit only. As well as mongoose nutrition must also be made so that the mongoose survives while producing civet coffee. The second largest component is packaging fuel with an amount of IDR. $5,000,000$ / year, the raw material for civet coffee uses arabica coffee with an amount of 
IDR. 9,650,000 / year, while the smallest cost is in fuel costs with an amount of IDR.. 3,101,000 / year.

\section{Acceptance}

The receipt of Mr. Suwandi's Luwak coffee business comes from the receipt of sold civet coffee with the value of cash received by Mr. Suwandi for the sale of civet coffee. Acceptance of Mr. Suwandi Luwak coffee business in Bandung Jaya Village, Kabawetan Subdistrict, Kepahiang Regency for one year was IDR. 255.00,000 / year.

Table 2. Variable costs of luwak coffee business in Bandung Jaya Village, Kabawetan District, Kepahiang Regency

\begin{tabular}{|c|c|c|c|c|c|}
\hline No & Description & Unit & Total/ year & IDR/year & Percent (\%) \\
\hline \multirow[t]{4}{*}{1} & Feed & & & & \\
\hline & Papaya & $\mathrm{Kg}$ & 900 & 2.700 .000 & 12 \\
\hline & Milk & $\mathrm{Kg}$ & 240 & 1.920 .000 & 8 \\
\hline & Chicken head & $\mathrm{Kg}$ & 36 & 540.000 & 2 \\
\hline \multirow[t]{3}{*}{2} & Fuel & & & & \\
\hline & Gasoline Liter & Liter & 252 & 2.016 .000 & 9 \\
\hline & Liter Oil & Liter & 31 & 1.085 .000 & 5 \\
\hline \multirow[t]{3}{*}{3} & Packaging Materials & & & & \\
\hline & Black Aluminum Seed & Biji & 2000 & 3.000 .000 & 13 \\
\hline & Seed Stickers & $\mathrm{Biji}$ & 2000 & 2.000 .000 & 9 \\
\hline \multirow[t]{2}{*}{4} & Raw Material Costs & & & & \\
\hline & Arabica Coffee & $\mathrm{Kg}$ & 1900 & 9.650 .000 & 42 \\
\hline \multicolumn{2}{|c|}{ Total Variable Cost } & & & 22.911 .000 & 100 \\
\hline
\end{tabular}

Source: Primary Data Processed (2018)

Table 3. Total revenue of luwak coffee business in Bandung Jaya Village, Kabawetan District, Kepahiang Regency

\begin{tabular}{ccccc}
\hline No. & \multicolumn{4}{c}{ Production of Luwak Powder Coffee } \\
\cline { 2 - 5 } & Month & $\begin{array}{c}\text { Amou- } \\
\text { nt (Kg) }\end{array}$ & $\begin{array}{c}\text { Price } \\
(\mathrm{Rp})\end{array}$ & $\begin{array}{c}\text { Total (Rp / } \\
\text { Kg) }\end{array}$ \\
\hline 1 & $\begin{array}{l}\text { January - } \\
\text { March }\end{array}$ & 35 & 600.000 & 21.000 .000 \\
2 & $\begin{array}{l}\text { April - } \\
\text { June }\end{array}$ & 40 & 600.000 & 24.000 .000 \\
3 & $\begin{array}{l}\text { July - } \\
\text { September } \\
4\end{array}$ & 38 & 600.000 & 22.800 .000 \\
$\begin{array}{l}\text { October- } \\
\text { December }\end{array}$ & 57 & 600.000 & 34.200 .000 \\
\hline Total / year & 170 & 2.400 .000 & 102.000 .000 \\
\hline Average / year & 42,5 & 600.000 & 255.00 .000
\end{tabular}

Source: Primary Data Processed (2018)

Based on the data in table 4 above, it can be seen that the income obtained by Mr. Suwandi's Luwak coffee business is IDR. 21,000,000 for January-March. For April-June IDR. 24,000,000. While the July-September number is IDR. 22,800,000 and for OctoberDecember the amount is IDR. 34,000,000. this month was the biggest acceptance received by
Luwandi Mr. Luwak's coffee business, because this month many consumers ordered civet coffee into Mr. Suwakdi. Due to being close to Christmas and New Year's Day. And for this month expenditure is not too large compared to other months because in other months consumers have more expenditure due to school holidays, fasting month and Eid.

\section{Income}

Luwandi Mr. Luwan's coffee business income is obtained from the calculation of the total revenue minus the total production costs. Where will generate income that will be used as a benchmark whether Mr. Suwandi's business has been profitable or lost. The income of Luwan Mr. Suandi's coffee business can be seen from the following table:

Table 3. Business income of luwak coffee Mr. Suwandi in Bandung Jaya Village, Kabawetan District, Kepahiang Regency

\begin{tabular}{cll}
\hline No & \multicolumn{1}{c}{ Description } & IDR / Year \\
\hline 1 & Total Revenue & $105,000,000$ \\
2 & Total Production Costs & $58,364,333.33$ \\
\hline & Income & $46,635,667$ \\
\hline
\end{tabular}

Source: Primary Data Processed (2018) 
From the data in table 5 above, we can see that the income of Mr. Suwandi's Luwak coffee is IDR. 46,635,667/ year. Where the total revenue is IDR. 105,000,000 / year is reduced by the total production costs at a cost of IDR. $58,364,333.33$ / year. Then we can conclude that the income that Mr. Suwandi has is very large or profitable.

\section{Efficiency Analysis}

\section{R / C Ratio Analysis}

Business efficiency analysis shows the calculation of R / C Ratio with the results obtained at 1.8. This value is obtained from the receipt of IDR. 102,000,000 / year, divided by the total production costs at a cost of IDR. $58,364,333.33$ / year and the result is 1.8 or $>1$, meaning that Mr. Suwandi's Luwak coffee business can be declared as a business that is in the "Efficient" category. The figure shows that in every Rp.1 cost incurred by Mr. Suwandi in his civet coffee business, a net income of IDR. 1.8 .

\section{B / C Ratio Analysis}

Benefit Cost Ratio is a comparison of the amount of the present value of the benefits and expenses of the coffee industry business during its economic life. This ratio or comparison must be greater than 1 . The greater the difference between 1 , the smaller the project risk / industrial business or investment risk (investment risk) (Sulianti, I and Lina F.T, 2013).

According to Tirta, P.W.W.K (2012) if the value of $B$ / $C$ ratio is greater than one, the project / industrial business is declared feasible. Then if the B / C ratio is equal to one then the project is called break even, whereas if the $\mathrm{B}$ / $\mathrm{C}$ ratio is smaller than one then the project or industry is declared loss.

The business feasibility analysis shows the calculation of B / C Ratio with the results obtained at 0.8 . This value is obtained from the income of IDR. 46,635,667 / year, divided by the total production costs at a cost of IDR. $58,364,333.33$ / year and the result is 0.8 or $<1$, meaning that Mr. Suwandi's Luwak coffee business can be declared as a business that falls into the category of "not feasible or loss". The figure shows that in every Rp.1 cost incurred by Pak Suwandi in his civet coffee business, a net income of IDR. 0.8.

\section{CONCLUSION AND RECOMMENDATION}

\section{Conclusion}

Based on the results of the analysis and discussion, a number of conclusions can be drawn from the Luwandi Luwak coffee business worthy of being developed. It can be seen that the total production costs with a value of IDR. 58,364,333.33 / year while the income earned is IDR. 289,635,667 / year.

In the calculation of the $\mathrm{R} / \mathrm{C}$ ratio with the results obtained at 1.8 . This value is obtained from the receipt of IDR. 102,000,000 / year, divided by the total production costs at a cost of IDR. 58,364,333.33 / year and the result is 1.8 or $>1$, meaning that Pak Suwandi's Luwak coffee business can be declared as a business that is in the "Efficient" category. And from the calculation of B / C Ratio, it can be seen that Luwak Luwak coffee business is not profitable. With an income of IDR. 46,635,667 / year, divided by the total production costs at a cost of IDR. 58,364,333.33 / year and the result is 0.8 or $<1$, meaning that Mr. Suwandi's Luwak coffee business can be declared as a business that falls into the category of "not feasible or loss".

\section{Recommendation}

- To business owners to better market civet coffee outside Sumatra. If you can, go abroad to get more income than before. And for the production process, it is expected to maintain cleanliness. Use gloves so that when filling in the coffee into the coffee package, the result will be more hygienic.

- To owners more minimize costs, both variable and fixed costs. In order to get a bigger income.

- For the government so that small-scale businesses or small-scale micro-businesses can develop more and develop this business so that they are always progressing and do not arrive at bankruptcy.

\section{REFERENCES}

Soekartawi. 2002. Ilmu usaha tani dan peneliti untuk pengembangan petani kecil. Universitas indonesia Press. Jakarta

2003. Agribisnis Teori dan Aplikasinya. Raja Grafindo Persada. Jakarta. 
Soleh, M. 2003. Perbaikan Mutu dan Keamanan Pangan Produk Olahan Hasil Industri Kecil Melalui Analisa Bahaya dan Penentuan Titik Kendali. Dalam Buletin Teknologi dan Informasi Pertanian. vol 6. Departemen Pertanian Badan Penelitian dan Pengembangan Pertanian(BPTP). Jawa Timur.

Sulianti, I, dan Lina Flaviana Tilik. 2013. Analisis Kelayakan Finansial Internal Rate of Return (IRR) dan Benefit Cost Ratio (BCR) pada Alternatif Besaran Teknis Bangunan Pasar Cinde Palembang. Jurnal Polsri. 8(1):834-835

Tirta , P.W.W.K. 2012.Kanalisis Kelayakan Finansial Pengembangan Usaha Kecil Menengah (Ukm) Nata De Coco Di Sumedang, Jawa Barat. Jurnal Inovasi Dan Kewirausahaan. 1(2):117-118
Widianti, Erlin. 2010. Analisis Usaha Kerupuk Pathilo Skala Rumah Tangga Di Kabupaten Wonogiri. Fakultas Pertanian Universitas Sebelas Maret Surakarta (Skripsi) sudah di publikasi. Diakses 06 Juni 2017.

Wijaya, S.S, Anhar Solichin, dan Dian Wijayanto2 dan Faik Kurohman2. 2011. Produktivitas Dan Kelayakan Usaha Tuna Longliner Di Kabupaten Cilacap Jawa Tengah.Jurnal Saintek Perikanan. 6(2), 2011

Wirakartakusumah, M. A. 1997. Telaah Perkembangan Industri Pangan di Indonesia Dalam Jurnal Pangan . 8(32). Penerbit Bulog. Jakarta. 